Jurnal Scripta Teologi dan Pelayanan Kontekstual
ISSN 2086-5368 (Print)
ISSN
Http://ejournal.stte.ac.id
Vol.2, No.1, pp. 12-22, 2017

\title{
Bimbingan Pastoral Kepada Kaum Muda Sebagai Upaya Peneguhan Iman Berdasarkan Ibrani 10:35
}

\author{
Yenny Anita Pattinama \\ STT Ebenhaezer Tanjung Enim \\ yennypattinam@gmail.com
}

\begin{abstract}
INFO ARTIKEL ABSTRAK
Sejarah Artikel:

Diterima : 05 April

Direvisi : 12 April

Disetujui: 20 April

Dipublikasi: 24 April

Kata Kunci:

Bimbingan, Pastoral,

Muda, Iman, Ibrani

10:35

Keywords:

keyword one,

Pemuda-pemudi adalah generasi ke depan dalam keluarga, gereja, dan bangsa. Pemuda-pemudi merupakan pondasi dan generasi penerus gereja yang harus dibina dengan baik. Masa depan gereja terletak pada generasi muda yang akan menggantikan para orang tua, untuk melanjutkan pelayanan dalam gereja sehingga gereja terus berkembang dengan baik. Namun, pemuda-pemudi zaman sekarang kurang memiliki ketaatan dan kesetiaan kepada Tuhan, sehingga dalam mempertahankan imannya kepada Tuhan Yesus sangat susah. Oleh karena kurangnya bimbingan rohani sebagai pondasi dalam kehidupan mereka untuk membentengi setiap godaan maupun tawaran dunia yang membuat iman mereka hilang. Orang tua dan gereja sangat berperan penting dalam pertumbuhan iman mereka. Jika pemudapemudi memiliki kerohanian yang baik, memiliki hubungan yang dekat denganTuhan, makaia juga pasti memiliki iman yang teguh dan dapat mempertahankan imannya di dalam Tuhan Yesus.
\end{abstract}

keyword two,

keyword three.

\footnotetext{
ABSTRACT

Young people are the next generation in the family, church and nation. Young people are the foundation and the next generation of churches that must be nurtured well. The future of the church lies in the younger generation who will replace the parents, to continue the ministry in the church so that the church continues to thrive. However, young people today have less obedience and loyalty to God, so that in defending their faith in the Lord Jesus is very difficult. Because of the lack of spiritual guidance as a foundation in their lives to fortify every temptation or offer of the world that makes their faith lost. Parents and the church are very important in the growth of their faith. If young people have a good spirituality, have a close relationship with God, then he also must have firm faith and can maintain his faith in the Lord Jesus.
} 


\section{PENDAHULUAN}

Tulisan ini menerangkan suatu periode transisi seorang manusia dari masa kanakkanak menuju dewasa. Inilah waktu seseorang memiliki perkembangan yang pesat akan pemikiran abstrak, mencari identitas diri secara psikologis, dan keinginan untuk dapat hidup mandiri.

Dalam perkembangan jaman yang semakin cepat di era globalisasi saat ini membuat anak-anak muda berusaha tampil dengan mengikuti tren yang sedang berkembang kecenderungan anak-anak muda adalah berusaha untuk bisa dapat pengakuan dari lingkungan sekitarnya. Mereka berusaha agar dapat diterima dalam lingkungan pergaulannya yaitu dengan cara mengikuti tren yang ada saat ini. Jika mereka tidak mengikuti tren yang sedang berkembang, maka mereka akan dianggap ketinggalan jaman dan kurang pergaulan.

Pemuda disamping harapan bangsa, dalam kenyataannya pula, pemuda kerapkali menjadi sumber permasalahan pembangunan yang dapat menghambat gerak maju roda pembangunan itu sendiri. Pemuda yang keadaannya tetap sebagai pelopor tidak lagi mempelopori pembangunan melainkan justru mempelopori gangguan-gangguan terhadap pembangunan yang gencar-gencarnya dilaksanakan oleh suatu bangsa dan Negara. Hal ini dimungkinkan dengan tiadanya atau hilangnya kesadaran pemuda untuk memainkan perannya di suatu bangsa secara benar dan bertanggung jawab.

Keasadaran pemuda untuk berperan secara benar dan bertanggung jawab atas kehidupan bangsanya pada masa kini maupun masa mendatang merupakan langkah awal dalam pembangunan dan membentuk generasi muda. Gejolak kehidupan sering mencekam para muda-mudi dan merupakan tantangan yang harus dihadapi sebelum mereka benar-benar memasuki alam kedewasaan.

Masa muda adalah suatu masa yang indah sekali. Pada masa muda terbukalah berbagai macam kesempatan dalam hidup yang memberi penghargaan yang serba gemilang. Pada umumnya orang mengambil keputusan-keputusan terpenting dan terbesar dalam kehidupannya pada masa muda, seperti menentukan mata pencarian dan memilih teman hidup. Dan biasanya pada masa muda pulalah orang mengambil keputusan mengenai perkara-perkara rohani yang kekal. Masa muda juga masa yang penuh dengan emosi dan semangat yang meluap dan memiliki jiwa yang penuh gairah dan gelora hidup. Bahkan mereka mencari identitas diri untuk bebas, lepas, tidak ingin dijadikan produk orangtua untuk terus menerus menuruti yang dikehendakinya. Artinya mereka sedang berjuang mencari identitasnya, sehingga tidak mau mendengar nasihat orang lain, tetapi ingin dibentuk oleh diri sendiri. Mengenai pemuda-pemudi pada jaman sekarang, seringkali menjadi masalah bagi orang tua dan orang lain. Memang benar bahwa pada masa muda itu adalah masa yang cemerlang. Tetapi masa itu juga merupakan suatu masa di mana banyak orang muda menjadikan kehidupannya suatu kegagalan dan kehancuran.

Di zaman sekarang banyak kita jumpai orang-orang yang sudah tidak ingat lagi kepada Tuhan bahkan pergi ke Gereja pun sudah jarang, terutama di kalangan mudamudi dan remaja, bahkan sering sekali mereka lupa untuk mengucapkan syukur pada sang Pencipta. Iman mereka goyah akibat kesenangan duniawi sesaat yang mereka pikir itu adalah kenikmatan yang selalu dirasa baik untuk dipertahankan tapiternyata tidak, mereka salah menduga. Mereka selalu merasa diri mereka itu paling hebat, kebanyakan anak muda jaman sekarang berlagak gaul sehingga lupa semuanya. 
Sebagai harapan masa depan Gereja dan masyarakat, kaum muda berada dalam posisi antara harapan dan kecemasan, karena dengan hadirnya globalisasi kaum muda di satu pihak menemukan jati dirinya melalui sikapnya yang individualistis, tetapi di lain pihak kaum muda mengalami krisis dalam pencarian iman mereka, karena mereka dihadapkan pada dua sisi kehidupan yang saling berseberangan, yaitu antara yang rohani dan yang jasmani. Dalam kehidupan pergaulan muda-mudi saat ini sangat membawa pengaruh negatif dalam perkembangan zaman. Karena itu gereja sebagai wadah yang harus lebih berperan dalam mendidik bahkan menanamkan iman terhadap mereka supaya semakin bertumbuh di dalam Tuhan. Sehingga muda-mudi dapat menyikapi perkembangan zaman bahkan menghadapi tantangan hidup yang mereka alami. Y. Singgih D. Gunarsa \&Singgih D. Gunarsa dalam bukunya "Psikologi Untuk Muda-Mudi" mengatakan bahwa:

Sejak saat seorang manusia dilahirkan, mulailah suatu masa perjuangan untuk mempertahankan hidupnya. Hanya mereka yang cukup kuat dan dapat bertahan terhadap segala gangguan, ancaman keamanan dan penyakit akan berhasil mencapai masa dewasa. Muda-mudi dengan masalah, pengalaman dan kesulitan-kesulitannya bila tidak memperoleh bimbingan dan pengarahan, akan seperti layangan yang putus terbawa angin yang entah dimana kelak tersangkut. Agar mencapai masa depan yang gemilang, muda-mudi ini harus mengalami persiapan yang matang. Dengan demikian mereka tidak lagi menghadapi masa depan yang suram akan tetapi masa dewasa yang berhasil.

Banyak sekali pemuda-pemudi jaman sekarang ini salah jalan karena salah pergaulan. Seharusnya mereka menyadari, mana pergaulan yang baik dan mana yang tidak baik. Karena kebanyakan pemuda-pemudi dalam memilih pergaulan, mereka hanya mencari orang-orang yang bisa menyenangkan hatinya. Dan jika hatinya merasa senang dan nyaman, dia merasa itu yang diinginkannya dan tidak peduli lagi apakah orang yang dia ajak bergaul, orang baik-baik atau bukan.

Keadaan yang memprihatinkan adalah adanya fakta bahwa pada saat ini banyak pemuda-pemudi tidak dapat mengendalikan diri dan mudah terbawa arus. Hal ini terlihat pada gaya hidup pemuda-pemudi yang ingin hidup bebas dan tidak terikat oleh aturan atau norma. Mereka cenderung mengabaikan nasihat yang diberikan (baik orang tua maupun orang lain), suka berbohong, melakukan hal-hal yang tidak senonoh terutama dalam hal berpacaran. Akibatnya, banyak pemuda-pemudi Kristen mengalami kemerosotan nilai moral dan kerohanian.

Kaum muda semakin bersikap individualistis, acuh tak acuh tehadap yang lain, menjadi manusia konsumtif, hedonistis dan lain sebagainya. Sikap individualistis yang diagung-agungkan oleh kaum muda menandakan bahwa mereka telah mengalami "kemajuan" dan kebebasan dalam menentukan pilihan mereka sendiri. Mereka seharusnya generasi atau penerus dalam setiap perkembangan di dalam gereja.

\section{METODE PENELITIAN}

Penelitian ini adalah penelitian kualitatif dengan pendekatan grammatical analysis. grammatical analysis adalah "the first stage of determining the inner cohesion of the text is to analyze the relationships entween the individual units or terms in the next". (Osbone; 1991:19).

Teknik pengumpulan data dalam penelitian ini dilakukan dengan pengamatan atau partisipasi langsung dan penelaahan dokumen.

Analisis data yang digunakan dalam penelitian ini mengikuti langkah-langkah grammatical analysis. Langkah penafsiran yang akan ditempuh sebagai berikut: 1 ). Teks 
Ibrani 10:35 akan ditafsirkan ayat demi ayat; 2). Penafsiran tiap tiap ayat akan mengerucut kepada kalimat demi kalimat dan frasa demi frasa; 3). Penelusuran terhadap meaning dari setiap frasa.

\section{HASIL DAN PEMBAHASAN}

Dalam bagian ini penulis akan membahas tentang bimbingan pastoral menurut Ibrani 10:35. Untuk memperoleh makna yang terkandung di dalamnya, maka penulis membuat uraian eksegetis, sehingga ditemukan prinsip-prinsip Alkitabiah untuk membimbing orang kristen secara khusus pemuda-pemudi dalam mempertahankan imannya kepada Tuhan.

Pasal 10:35 merupakan nasehat dan larangan kepada para pembaca surat Ibrani ini supaya kuat dan berpegang teguh pada iman masing-masing sampai kepada kesudahannya. Dalam surat Ibrani 10 ini dijelaskan bahwa Yesus yang telah mempersembahkan diri-Nya sebagai korban yang sempurna untuk pendamaian dan perantara antara Allah dengan manusia. Dan itu satu kali untuk selama-lamanya. Juga dijelaskan bahwa Yesus telah melewati pederitaan yang sangat berat itu dengan taat dan setia. Untuk itu Penulis surat Ibrani menasehatkan pembaca surat ini sebagai orang-orang yang sedang mengalami penderitaan bahkan penganiayaan oleh karena iman supaya tetap bertahan, taat dan setia. Karena orang yang benar dan yang tetap bertahan menghadapi tantangan, akan hidup oleh imannya. Tetapi orang yang mengundurkan diri serta yang putus asa karena tantangan akan binasa dan tidak mendapat bagian mulia dari Allah.

Ibrani 10: 35 merupakan sebuah nasihat praktis kepada orang Yahudi yang telah percaya Kristus.Untuk memahami arti teks Ibrani 10: 35, maka penulis akan menguraikan analisa kata dari Ibrani 10:35.

\section{a. Frase "Sebab Itu Janganlah"}

Ayat 35 dimulai dengan kata "Sebab Itu Janganlah." Istilah sebab itu dalam bahasa aslinya ditulis oun ten yang artinya karena itu, maka, lalu, adapun, sebenarnya, sungguh, tetapi. Kata ini menjelaskan pada ayat-ayat sebelumnya, dimana orang-orang Yahudi Kristen yang tetap bertahan dalam cobaan ataupun tantangan. Kemudian kata janganlah dalam Bahasa aslinya di tulis " $\mu$ r'” (me). Kata ini berbentuk partikel negatif yang sering digunakan sebagai kata larangan yang memiliki arti tidak, jangan, pasti tidak, sesungguhnya tidak, sekali-kali takkan dan jangan, tidak, tidak ada, yang tidak, Tuhan melarang, kalau-kalau, tiada satupun. Kata " $\mu$ n'” (me) juga menunjuk pada suatu larangan dengan keras dan dilakukan berulang-ulang. Dalam Strong Exhaustive Corcondance of the Bible menterjemahkan kata " $\mu$ n'" (me) neither (tiada satu pun) never (jangan, tidak pernah), none (tidak ada), without (tanpa). NIV menterjemahkan "not by constraint" (tidak oleh batasan). Dalam Alkitab sehari-hari menterjemahkan “dengan senang hati”. Anton M. Moeliono menjelaskan istilah "janganlah" merupakan sebuah larangan, berarti tidak boleh; hendaknya tidak usah. Kata ini diletakkan di depan kata kerjà (apobalete).

Dengan demikian istilah "sebab itu janganlah" yang dimaksud dalam ayat ini adalah bahwa penulis Ibrani menyampaikan suatu nasehat sekaligus larangan yang keras dengan sungguh-sungguh kepada orang Yahudi yang sudah percaya. Dan ini 
disampaikan oleh penulis kepada mereka dengan berulang-ulang supaya jangan putus asa dalam semuanya itu. Di ayat sebelumnya sudah dijelaskan bagaimana mereka memperjuangkan iman itu dengan melewati penderitaan bahkan godaan-godaan. Sehingga penulis perlu mengingatkan mereka supaya jangan putus asa sampai pada hari kesudahannya. Jika mereka tidak bisa mempertahankan iman yang sudah mereka pegang, sehingga berbalik dari apa yang mereka yakini selama ini, maka akan ada akibatnya yang diterima sebagai konsekuensi dari ketidaksetiaan mereka.

\section{b. Frase "Kamu Melepaskan"}

Kata selanjutnya dalam ayat 35 yaitu, "kamu melepaskan”. Dalam bahasa aslinya ditulis (apobalete) yang berasal dari kata apoballo yang memiliki arti menanggalkan (pakaian), membuang, hilang. Kata ini ditulis dalam bentuk kata kerja aorist aktif orang kedua jamak subjunctive. Yang menjelaskan suatu pekerjaan yang pernah dilakukan hanya sekali, tetapi terus-menerus. Kata (apoballo)ditulis dalam Perjanjian Baru sebanyak dua kali.

Dalam Strong Exhaustive Corcondance of the Biblementerjemahkan kata $\dot{\alpha}$ (apoballo) to throw off (membuang, melemparkan, mencampakkan), to lose (hilang, lenyap). Sedangkan dalam NIV menterjemahkan throw away yang artinya melepaskan peluang, di buang setelah digunakan. Dalam kamus Yunani diartikan menanggalkan (pakaian), menghilangkan, melepaskan.

Dengan demikian istilah "kamu melepaskan" yang dimaksud dalam ayat ini adalah mengacu kepada orang-orang Kristen Ibrani. Istilah sebelumnya kata "sebab itu janganlah" kemudian diikuti dengan istilah "kamu melepaskan" adalah mereka yang sudah percaya Yesus diperintahkan dengan keras bahwa sesuatu yang sudah ada dalam hidup mereka yaitu Yesus yang telah mereka terima juga percayai saat itu untuk tidak dibuang, ditanggalkan, bahkan menghilangkannya dari kehidupan mereka oleh karena pengaruh lingkungan yang menggoyahkan iman mereka.

Penulis surat Ibrani ini hendak menyampaikan suatu perintah kepada para pembaca pada saat itu yang telah menerima semua pengajaran yang telah didengar dan dilihat haruslah terus dilakukan pada waktu sekarang ini tanpa henti-hentinya. Penjelasan di atas membawa kepada suatu kesabaran serta nasehat dari penulis supaya tidak tergesa-gesa dalam mengambil keputusan yang salah, apalagi dalam menghadapi tantangan yang sangat berat.

\section{c. "Kepercayaanmu"}

Kata selanjutnya dari ayat 35 "kepercayaanmu", dalam Alkitab bahasa Indonesia sehari-hari ditulis keyakinan. Bahasa aslinya (parresian) yang berasal dari kata (parresia) yang artinya keterus-terangan, di depan umum, keberanian, keyakinan. Ditulis dalam bentuk kata benda tunggal akusatif feminin. Ini menjelaskan tentang pengajaran ayat-ayat sebelumnya yang diterima oleh orang-orang Yahudi yang sudah percaya dan itu diyakini oleh mereka menjadi suatu kepercayaan. 
Dalam Linguistic Key toThe Greek New Testament diterjemahkan boldness, confidence yang artinya keberanian, kepercayaan. Dalam StrongExhaustive Corcondance of the Bible menterjemahkan confidence, freely, openly, plain, yang artinya kepercayaan, dengan bebas, secara terbuka, polos. Sedangkan dalam Exegetical Dictionary of the New Testament dikatakan openness, publicness, condor, confidence yang artinya keterbukaan, umum, sifat ikhlas, kepercayaan. Dalam Analytical Greek Lexicon Revised dikatakan freely, boldly, assurance artinya dengan bebas, dengan terus terang.

Dengan demikian dapat disimpulkan bahwa penulis surat Ibrani mau menyampaikan kepada orang-orang Kristen penerima surat ini bahwa kepercayaan yang mereka miliki bukan untuk disembunyikan melainkan dinyatakan dengan keterusterangan, secara terbuka lewat apa yang mereka hadapi saat itu, supaya orang-orang Yahudi yang belum mengenal Yesus melihat keyakinan mereka yang kokoh di dalam Tuhan.

\section{d. Frase "Besar Upah"}

Ayat 35 dilanjutkan dengan kata "Besar Upah", dalam bahasa aslinya (megalen misthapodosian). Kata (megalen)berasal dari kata (megas) yang artinya besar, agung, panjang, luas, lanjut, kaya, nyaring, terang, ganjil, penting, keras, sangat, dasyat, sombong, ditulis 243 kali dalam Perjanjian Baru. Kata ini ditulis dalam bentuk adjektif tunggal akusatif feminin no degree. Yang menunjuk pada suatu kata sifat dan mau menjelaskan kata yang ada depannya.

Dalam Strong Exhaustive Corcondance of the Bible menterjemahkan kata (megas) exceedingly, great, high, large, loud, mighty, sore, strong yang artinya sangat, hebat, tinggi, besar, nyaring, maha, kuat. Dalam New Americand Standard Bible menterjemahkan menjadi has a great yang artinya memiliki suatu kehebatan.

Sedangkan dalam The NIV Study Bible New International Version diterjemahkan it will be richly yang artinya secara mewah. Kata (megas) disini bukan berarti suatu ukuran yang sering digunakan oleh manusia untuk menunjuk kepada sesuatu benda yang besar. Tetapi (megas) adalah sesuatu yang agung, besar, hebat, mewah yang diberikan oleh Allah sendiri kepada seseorang. Kemudian kata (misthapodosian) berasal dari kata (misthapodosia) yang memiliki arti upah, pahala, hukuman. ditulis tiga kali dalam Perjanjian Baru. Kata ini ditulis dalam bentuk kata benda tunggal akusatif feminin. Yang menjelaskan sesuatu yang ada pada ayat sebelumnya yang mereka perjuangkan. Dalam Exegetical Dictionary of the New Testament diterjemahkan payment, reward, retribution yang artinya pembayaran, ganjaran, hadiah, retribusi, balas jasa, ganti rugi. Sedangkan dalam The Bible Knowledge Commentary mengartikannya dengan rewarded yang artinya diberi penghargaan. Dalam The Complete World Study Dictionary New Testament menterjemahkannya dengan rewarder, a recompense, whether a reward, a punishment yang artinya membalaskan, satu imbalan jasa, satu imbalan, satu hukuman. 
Dengan demikian istilah "besar upah" dalam ayat 35 ini adalah suatu pemberian hadiah yang sangat mewah dan sebagai balas jasa yang telah dilakukan dengan perjuangan yang berat, dan ini tidak dapat di ukur dengan apapun. Disamping pengertian itu, istilah "besar upah" juga diartikan sebagai suatu hukuman yang sangat besar, yang sangat dasyat juga menakutkan yang tidak dapat dihindari oleh siapapun. Dan itu sebagai konsekuensi dari ketidaksetiaan terhadap apa yang diyakini selama ini.

Penulis surat Ibrani mau menyampaikan kepada orang-orang Yahudi yang sudah percaya Yesus yang telah berjuang dalam iman, supaya tetap setia dalam menghadapi setiap cobaan. Jika mereka tetap setia ataupun bertahan dalam kepercayaan mereka, maka janji Tuhan tentang upah yang besar itu akan menantikan mereka. Penulis terus mendorong para pembaca surat ini supaya tetap bertekun di dalam Tuhan.

\section{MAKNA THEOLOGIS SURAT IBRANI 10: 35}

Sesuai dengan pembahasan di atas, maka pada bagian ini penulis akan memaparkan makna theologis dari surat Ibrani 10:35, yang penulis dapatkan dari hasil eksegese.

\section{a. Memiliki Iman Yang Kuat Kepada Yesus Kristus}

Beriman berarti berpegang teguh pada keyakinan yang dimiliki akan suatu hal, karena hal itu dapat dipercaya dan diandalkan. Demikianlah iman selalu berkaitan dengan "percaya". Iman mendasari semua pengalaman Kristen sejati. Tanpa iman tidak mungkin seseorang berkenan kepada Allah, iman juga berarti kepercayaan akan kebenaran Yesus Kristus yang disalibkan dan telah bangkit. Iman itu meliputi tanggung jawab pribadi yang aktif kepada Allah dalam Kristus dan bukan hanya kesadaran akan realitas Allah. James Strong menjelaskan tentang iman, yaitu;

Pertama, keyakinan yang kokoh bahwa Yesus Kristus adalah Anak Allah dan satusatunya Juruselamat umat manusia.

Kedua, persekutuan yang menyangkal diri dan ketaatan kepada Kristus.

Ketiga, kepercayaan penuh di dalam Kristus bahwa la mampu dan bersedia menuntun seseorang hingga mencapai keselamatan kekal dan persekutuan dengan Allah di sorga.

Dengan demikian orang percaya yang mengakui Yesus sebagai Tuhan dan Jurus'lamat dalam hidupnya harus memiliki iman yang kuat kepada Tuhan sehingga tidak bisa digoyahkan oleh cobaan apapun, karena hidupnya selalu bergantung kepada Tuhan Yesus dan tetap memandang kepada-Nya yang setia dalam menghadapi setiap rintangan.

Dalam ayat 35 dikatakan "sebab itu janganlah" yang menunjuk pada suatu larangan yang keras. Dalam hal ini orang-orang Kristen Ibrani diperintahkan untuk tidak meninggalkan iman mereka kepada Tuhan, tetapi tetap setia dan memiliki iman yang kuat kepada Yesus Kristus supaya tidak goyah ketika dalam menghadapi setiap tantangan yang ada. Samuel Benyamin Hakh dalam bukunya Perjanjian Barumenjelaskan tentang kesetiaan dalam menghadapi tantangan;

Yesus adalah contoh yang paling penting. Ia setia dalam perjalanan-Nya. la tetap setia menanggung penderitaan di dalam peranan-Nya sebagai Imam Besar (2:10, 17; 5:8-9). Penderitaan-Nya begitu luar biasa, sehingga la berseru kepada Allah dalam 
ratap tangis dan air mata. Ia rela memikul salib dan mati di kayu salib. Namun, la tetap setia dalam penderitaan-Nya itu, sehingga masuk dalam sukacita sorgawi.

Oleh karena itu, Yesus menjadi teladan bagi kita orang percaya untuk menghadapi segala sesuatu dengan taat dan setia sebagai bukti bahwa kita memiliki iman yang kuat di dalam Dia.

\section{b. Tekun Dalam Mengikut Tuhan}

Tekun membawa seseorang kepada kesabaran dalam menghadapi segala sesuatu. Kesabaran yang dimaksud adalah suatu keputusan, sikap yang tidak tergesagesa tetapi juga tidak menunda-nunda, namun berjalan terus dengan pasti dan tidak mau dibelokkan. Rintangan tidak akan menakutkan, hambatan tidak akan menghapuskan pengharapannya. Kesabaran itu adalah kesabaran yang tabah, yang terus bertahan hingga mencapai tujuan. Sabar berarti tunduk, berserah sepenuhnya pada kehendak Allah, dan tidak memberontak, marah kepada Allah, pada waktu kita mengalami penderitaan. Ketekunan adalah ketetapan hati yang kuat dan teguh untuk bersungguh-sungguh dalam melakukan tugas apapun. Kata tekun diartikan (hupomeno)yang artinya tinggal, bertahan, menangung, sabar. Juga menyatakan daya tahan untuk melawan agar tidak menyerah, dan seperti halnya tetap tekun dalam keadaan yang sulit, tekun juga berarti fokus, konsisten dan tidak mudah putus asa terhadap apa yang sedang dikerjakannya. Alkitab mencatat, Sebab kamu memerlukan ketekunan, supaya sesudah kamu melakukan kehendak Allah, kamu memperolah apa yang dijanjikan itu" (Ibr. 10:36). Dalam ayat 35 sebelumnya dikatakan kata "sebab itu janganlah" kemudian diikuti dengan istilah "kamu melepaskan" adalah mengacu kepada mereka yang sudah percaya Yesus artinya supaya tidak melepaskan, atau membuang apa yang sudah dimiliki. Maka dalam hal itu diperlukan suatu ketekunan dalam memperjuangkan apa yang sudah dipegang dan dipercayai itu. Karena jika seseorang tekun dalam hal itu, dia tidak akan pernah tergoyahkan, bahkan menghilangkan kepercayaannya, oleh karena pandangannya terus tertuju kepada Allah.

Penulis Ibrani menasehati orang-orang Kristen supaya tidak tergesa-gesa dalam mengambil keputusan yang salah ketika dalam menghadapi tantangan yang sangat berat. Penulis juga mengingatkan para pembaca yaitu orang-orang Kristen Ibrani yang hidup dalam kesukaran dan penderitaan, mereka mengalami penganiayaan dan tekanan seperti, menderita kerugian, diejek, banyak yang mengalami pencobaan, kehilangan hak khusus, dianiaya, dicemooh, dan dibenci secara terbuka oleh sesama orang Yahudi, dijadikan tontonan umum, dan harta benda mereka dirampas oleh karena mereka adalah orang Kristen, untuk tetap tekun di dalam Iman, pengharapan dan kasih kepada Kristus.

\section{c. Dalam Ketaatan Dan Kesetiaan Ada Upah Yang Besar}

Kata taat dalam Kamus besar bahasa Indonesia, memiliki arti sikap yang senantiasa menurut (kepada Tuhan, Pemerintah, dsb), patuh, tidak berlaku curang, setia, kuat beribadah. Secara harfiah kata ini berarti mendengarkan dalam Perjanjian Baru memakai kata (Peithomai) tunduk, patuh dan (Peitharkheo) menaati, menuruti, mendengarkan". Kedua kata ini menggambarkan pikiran yang menyerah pada bujukan dan tunduk kepada kekuasaan. Ketaatan yang dimaksud dalam hal ini adalah ketaatan 
kepada Allah dan Yesus Kristus (2Kor. 10: 5; 1Ptr. 1: 2). Ketaatan hanya melalui iman yang bersumber dari percaya kepada Allah dan Firman-Nya.

Istilah "Kesetiaan". Dalam KJV dan NIV kata "kesetiaan" memakai istilah "faith", dalam Alkitab Bahasa Indonesia Sehari-hari dikatakan "setia pada ajaran-Nya". Dalam kamus Teologi Inggris-Indonesia Faith berarti percaya, iman, sedangkan kata kesetiaan ialah Faitfulness. Kata "setia" ditulis dalam terjemahan bahasa Yunaninya ialah (pistin)berarti faith atau faithfulness artinya kepercayaan, iman, kesetiaan, agama, ajaran yang diimani, janji atau bukti. Berarti Iman adalah suatu pokok dan hasil yang penting dalam hubungan dengan Allah dalam Kristus: penerimaan dengan penuh kepercayaan dan pengakuan dari apa yang Allah telah lakukan dan la janjikan. Jadi iman itu bukan hanya perkataan yang keluar dari mulut seseorang saja, namun lebih dari itu iman harus direalisasikan dengan tindakan nyata melalui kesetiaannya kepada yang ia percayai. Objek iman itu adalah Allah yang telah menyatakan diri dalam Yesus Kristus, dan iman tidaklah tinggal statis, namun iman itu harus bertumbuh. Jadi, seseorang yang memiliki ketaatan dan kesetiaan dalam mengerjakan segala sesuatu dalam kehidupannya ia akan mendapat imbalan atau balas jasa sebagai upah terhadap apa yang dikerjakannya.

Dalam hal ini penulis Ibrani mengatakan kepada para pembaca yaitu orang-orang Kristen Ibrani bahwa ada upah yang sangat besar yang dimiliki oleh orang yang taat dan setia. Upah yang akan didapat itu adalah pemberian Tuhan yang tidak dapat diberikan oleh manusia dan tidak dapat diukur oleh apapun yang ada di dunia ini. Dengan demikian, orang-orang Kristen Yahudi tidak mudah untuk mendapatkan upah yang besar, karena membutuhkan perjuangan yang berat melalui hidup dalam ketaatan dan kesetiaan kepada Tuhan.

\section{KESIMPULAN}

Berdasarkan uraian di atas dapat disimpulkan bahwa penulis Ibrani hendak mengatakan kepada penerima surat Ibrani yaitu orang-orang Yahudi yang sudah percaya kepada Yesus supaya mereka jangan melepaskan apa yang mereka yakini atau percayai. Karena jika mereka tetap mempertahankan atau memperjuangkannya akan ada upah yang didapat yaitu upah sorgawi. Ini adalah janji-Nya bagi mereka yang tetap setia kepada-Nya.Jugasebaliknya, jika mereka tidak dapat mempertahankan apa yang mereka percayai selama ini, melainkan melepaskan, akan ada yang didapat sebagai konsekuensi dari ketidaksetiaan itu. Memang tidak mudah untuk mempertahankan apa yang sudah mereka yakini, berbagai tantangan, cobaan yang akan dihadapi oleh mereka yang berusaha menggoyahkan kepercayaan mereka kepada Yesus. Namun penulis Ibrani mengingatkan mereka supaya memiliki kesabaran, ketekunan dan mata yang tertuju kepada Tuhan Yesus yang mereka percayai. 


\section{KEPUSTAKAAN}

Balz, Horst and Gerhard Schneider

1990 Exegetical Dictionary of the New Testament Volume 1, Michigan: William B. Eerdmans Publishing Company

Browning, W. R. F $2008 \quad$ Kamus Alkitab, Jakarta: BPK Gunung Mulia

Doughlas, J.D. $2002 \quad$ Ensiklopedi Alkitab Masa Kini Jilid II, Jakarta: YKBK

Gunarsa, Y. Singgih D. \& Singgih D. Gunarsa $1991 \quad$ Psikologi Untuk Muda-Mudi, Jakarta: BPK Gunung Mulia Hawkins, Joyce M. 1999 Oxford Erlangga Kamus Dwibahasa, Jakarta: Erlangga,

Milne, Bruce 1993 Mengenali Kebenaran, Jakarta: BPK Gunung Mulia, Moulton, Harold K. 1978

The Analytical Greek Lexicon Revised, Michigan: Zondervan Publishing House Grand Rapids

Newman, Barclay $1991 \quad$ Kamus Bahasa Yunani Indonesia, Jakarta: BPK Gunung Mulia,

Raines \& Richardson $1980 \quad$ Asas-asas Alkitab Bagi Kaum Muda, Bandung: Kalam Hidup Rienecker, Fritz \& Cleon Rogers tt Linguistic Key to The Greek New Testament, Germany: Seeheim, Siagian, Novelina Margaretta $2008 \quad$ Urgensi Pemahaman II Timotius 3:19 Sebagai Antisipasi Pergaulan

Strong, James 1990 Strong's Exhautive Concordance of Bible, Virginia: Mac Donal

Sutanegara, HC. H. Ramli Publishing Company

1997 Milenium Pemuda, Palembang: PDK Kosgoro Sumatera Selatan, Tangdilintin, Philip 1984 Pembinaan Generasi Muda Visi dan Latihan, Jakarta: OBOR

Walvoord, John F. and Roy B. Zuck, 1986 The Bible Knowledge Commentary, England: Book A Division Of SP Publications

Wibowo, Paulus Trimanto $2000 \quad J a w a b a n$ Atas Pertanyaan Anda, Yogyakarta: Yayasan Andi

Zodhiates, Spiros 1993 The Complete World Study Dictionary New Testament, America: AMG Internatoinal

\section{INTERNET}

- http://www.buletinpillar.org/artikel/menghidupi-panggilan-sebagai-pemudapemudi-kristen, On Line 26 Juli 2014 
- http://sapereaudenias.blogspot.com/2008/08/kaum-muda-harapan-masadepan-gereja.html,On Line 26 Juli 2014

- http://www.renungan-spirit.com/pembaca/jatuh_bangun.html, On Linez6 Juli 2014

- http://sapereaudenias.blogspot.com/2008/08/kaum-muda-harapan-masadepan-gereja.html,On Line 26 Juli 2014

- http://rangkumankhotbah.blogspot.com/2012/08/memilih-pergaulan.html, On Line 26 Juli 2014

- http://sapereaudenias.blogspot.com/2008/08/kaum-muda-harapan-masa-depan gereja.html, On Line 26 Juli 2014

- http://medisontanesib.blogspot.com/2010/11/arti-pengharapan.html, Online 1 Oktober 2013

- http://www.pelitahidup.com/2009/08/10/berani-tampil-beda/, On Line 26 Juli 2014 